\title{
透析患者の定時薬服薬遵守率は医療スタッフの予測より高い
}

\begin{tabular}{|c|c|c|c|c|c|c|c|}
\hline 吉 野 & 秀 章 & 山下 & 万紀子 & 渡部 & さゆ & & 小 嶺 \\
\hline 矢 野 & 未来 & 川口 & 利 江 & 川口 & & 唯 & 江 藤 \\
\hline 左々木 & 修 & 一ノ瀬 & 浩 & 澤 瀬 & 健 & 次 & 橋口 \\
\hline $\begin{array}{l}\text { 田 } \\
\text { 崎腎病 }\end{array}$ & 孝 & 舩 越 & 哲 & & & & \\
\hline
\end{tabular}

キーワード：透析患者，透析スタッフ，薬剂，服薬率

〈要旨〉

維持透析患者は他疾患に比べ，総服薬数が多数となる傾向にあるが，患者服薬状況についての報告は少ない．今回 われわれは, 外来血液透析患者のうち, 服薬を自己管理している 172 名に対し定時薬の服薬遵守率（以下, 服薬率） や飲み忘れの有無, 服薬の自己調節の有無を聞き取り調査した. 同時に, 医療スタッフ（看護師・臨床工学技士） が予測する服薬率を薬剤別に調査し，患者の服薬率と比較した。 その結果，すべての薬剤において患者の服薬率が 医療スタッフの予測を上回る結果となった．このことは服薬遵守に関する情報と意思共有が，患者と医療スタッフ で十分になされておらず，医療スタッフが先入観を抱いている可能性がある. 今後は医療スタッフ自身の薬剤に対 する知識の充実, また患者の服薬状況を客観的に評価する姿勢が求められる. 加えて, 定期的な服薬率調査は質の よい服薬アドヒアランスに繋がる可能性が示された.

\section{Dialysis patients take prescribed medications more regularly than their healthcare providers assume}

Hideaki Yoshino, Makiko Yamashita, Sayuri Watanabe, Maya Komine, Miki Yano, Rie Kawaguchi, Yui Kawaguchi, Rika Etou, Osamu Sasaki, Hiroshi Ichinose, Kenji Sawase, Junichiro Hashiguchi, Takashi Harada, Satoshi Funakoshi

Nagasaki Kidney Center

Keywords: dialysis patients, dialysis personnel, medications, medication adherence rate 〈Abstract〉

While patients on maintenance dialysis tend to take more medications than other patients, very few studies have examined how healthcare providers estimate the medication adherence of such patients in the clinical setting. Of the outpatients receiving hemodialysis at our center, a total of 172 who self-administered their regular medications were surveyed using a self-administered questionnaire to assess their medication adherence rates(hereafter referred to as the adherence rate), missed medication doses, and self-adjusted medication doses. Concurrently, a separate survey of their healthcare providers (nurses and clinical engineers) was conducted to evaluate their estimates of adherence for each medication class. As a result, it was shown that the patients' self-medication behavior deviated from their healthcare providers' assumptions and that the patients were taking their prescribed medications more regularly than their healthcare providers had assumed. This suggests that the exchange of information about medication adherence between the patients and their healthcare providers was inadequate and that the healthcare providers had incorrect preconceptions about their patients. Overall, the study findings suggest a need not only for education on the role of pharmacotherapy and the risks associated with poor mediation adherence, among less adherent patients, but also a need to increase knowledge of rele-

吉野 秀章 医療法人衆和会長崎腎病院％ 850-0032 長崎県長崎市興善町 5-1

Hideaki Yoshino Tel：095-824-1101 Fax：095-824-1181

〔受付日：2016 年 12 月 26 日, 受理日：2017 年 7 月 4 日〕 
vant medications and promote an objective attitude toward the evaluation of patients' self-medication behavior, among healthcare providers.

\section{緒 言}

わが国の慢性維持透析患者数（以下，透析患者数） は 2015 年末の時点で 324,986 名であり年間透析導入患 者数は 39,462 名と年々増加している ${ }^{1)}$. 透析患者はほ かの慢性疾患患者に比べ食事や飲水量など日常生活の 制限も多いことに加え，比較的多くの薬剂を永続的に 服薬することが要求される 2 。 また透析関連医療の発 展とともに生存率も延長し ${ }^{1)}$, 循環器領域・骨代謝な どの透析合併症の割合も増加していることから ${ }^{3,4)}$, こ れらに対する治療を目的とした薬剤も加わっている. このほか, 有職の透析患者においては，仕事による時 間の拘束や，仕事外の社交による生活時間のずれなど に影響され，服薬する時間や間隔が不規則となること から，患者の服薬率を把握することはきわめて重要と 考えられる。しかしながら，透析患者を対象として服 薬状況の実態を調査した報告はあるものの ${ }^{5)}$, 同時に 医療スタッフ側の認識・予測を対応させた検討はなさ れていない.

今回，われわれは透析患者の服薬率と医療スタッフ 側が予測する服薬率との両者を調査し，その乘離の有 無や医療スタッフの予測の根拠などを検討した.さら に患者の服薬率を年代別や処方剂数, 薬剤の形体, 透 析時間帯など条件別に分析し，服薬アドヒアランスに 影響を与える因子について検討した.

\section{I．対象・方法}

対象は当院に通院する透析患者 302 名のうち服薬を 自己管理している 172 名で, 年齢は平均 $63.3 \pm 12.1$ 歳, 平均透析歴は $8.1 \pm 7.8$ 年, 性別は男性 112 名, 女性 60 名であった。なお，薬剤を一包化していた患者は全体 の $28.9 \%$ であり，その患者に対してもそれぞれの薬剤 の服薬率について調査した。 また認知症を有する患
者, 精神科受診中で診断名を有する患者は除外した. 医療スタッフは，当院血液浄化センター勤務の看護師 24 名と臨床工学技士 10 名の計 34 名で, 平均年齢 34.8 \pm 7.5 歳, 平均勤務年数 $7.7 \pm 7.3$ 年であった（表 1). 医師については 2 名のみであり，処方者であるため, 偏り（bias）の影響を考慮して除外した。また，医療 スタッフヘのアンケートに関しては無記名とした。薬 剤についての調查では当院において処方頻度が高い,

(1) シナカルセト塩酸塩, (2) 催眠 - 鎮静剤, (3) 活性型 ビタミン $\mathrm{D}_{3}$ 製剂, (4) 消化性潰瘍凨, (5) 降圧剂, (6) 緩 下剤，(7)リン吸着剤，8 カリウム抑制剂の 8 種におい て 1 日で服薬する薬効分類数を調査した.

\section{II . 倫理的配慮}

個人情報の保護の確約と, 本研究に協力しなかった 場合でも医療上の不利益は被らないことを主治医から 各患者に説明し, 院内の倫理委員会の承認を得て, 患 者からは文書にて同意を得た。本研究は，医療法人衆 和会臨床研究倫理審査（認証番号：27003, 承認日： 2015 年 1 月 30 日）の承認を得て実施した.

また，本研究は公的臨床研究登録機関に登録した (UMIN, R000029132).

\section{III. 方 法}

透析患者の服薬状況は聞き取り調査を行い，飲み忘 れの有無とその理由, 自己調節の有無とその理由を調 査し, 回答方法は「はい」,「いいえ」の二者択一とし た. また, 対象患者全員へ前述の 8 種の薬剤において, 1 日の処方数における薬剤の服薬率を調査した。次に 透析時間带別，処方剂数別，年代別の服薬率，さらに 服薬方法や薬剤の形体に特徴のあるリン吸着剤・カリ ウム抑制剤については，使用している薬剤の種類別に 分析した。飲み忘れ，自己調節した場合の回答は一度

表 1 患者背景と血液浄化センター勤務医療者

\begin{tabular}{c|c|c}
\hline \multirow{4}{*}{ 患者背景 } & 対象患者 & 男性 : 112 名 $(65.1 \%)$ 女性 : 60 名 $(34.9 \%)$ \\
& 年齢 & $63.3 \pm 12.1$ 歳 \\
& 透析歴 & $8.1 \pm 7.8$ 年 \\
& 処方剂数 $(1$ 日平均 $)$ & $9.8 \pm 3.4$ 刻 \\
\hline \multirow{3}{*}{ 医療スタッフ } & 血液浄化センター勤務者数 & 看護師 24 名 臨床工学技士 10 名 \\
& 年齢 & $34.8 \pm 7.5$ 歳 \\
& 勤務年数 & $7.7 \pm 7.3$ 年 \\
\hline
\end{tabular}




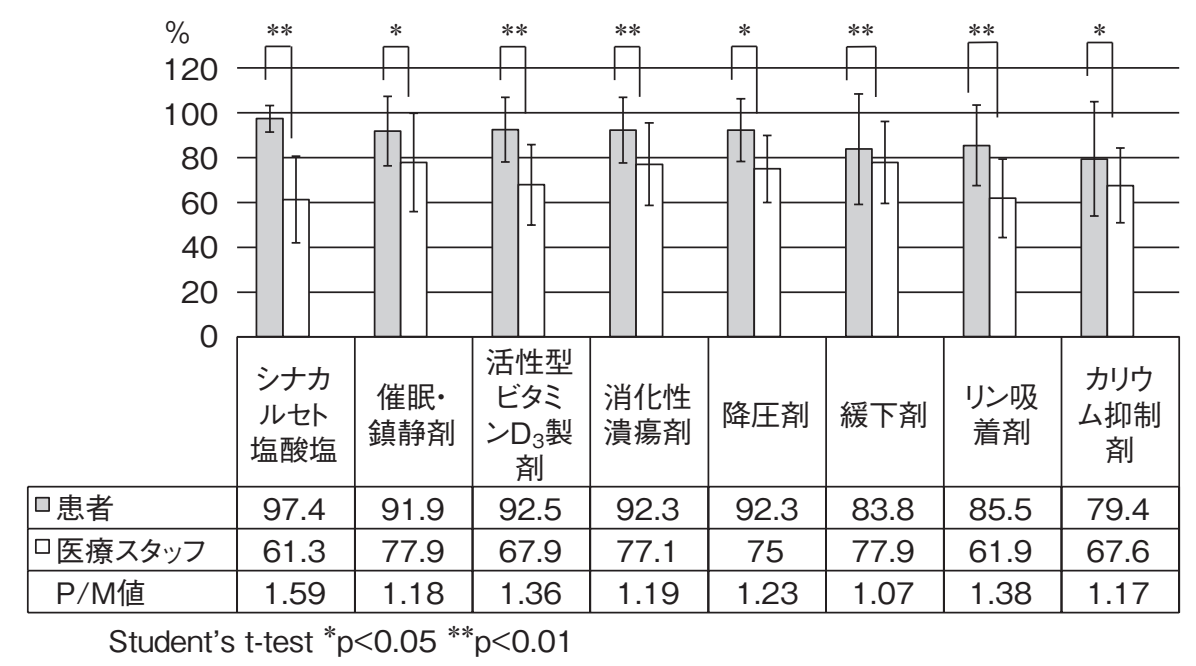

図 1 患者服薬率と医療スタッフ予測の比較

でも行った場合を含むため，個々の患者においてすべ ての薬剤ごとに飲み忘れ, 自己調節の頻度を申告させ るのは困難であることから，服薬遵守率とは別個の扱 いとした。

医療スタッフの予測する患者服薬率は対象薬剤の 8 種の服薬率について, 10 段階スケール票を当院独自で 作成し集計した。調査期間は 2015 年 1 月から 2015 年 4 月までの 4 か月間とした.

分析方法には Bell Curve ${ }^{\circledR}$ Ver2.0（株）（社会情報 サービス，東京，日本）を用い，年代別，患者の服薬 率と医療スタッフ予測の服薬率抢上び，「医療スタッ フが予測する服薬率 $(\mathrm{M}) 」$ 」「患者自己申告による服 薬率 $(\mathrm{P}) 」$ の比較にはStudent's t-testを行った。 そ の他, 透析時間带別 - 処方剂数別 ・ リン吸着剂種類 別・カリウム抑制剤種類別の服薬率の比較は KruskalWallis test を用いて差異を検討した．なお，有意水準 5\%以下をもって統計学的有意差ありと判定した.

\section{IV. 結 果}

透析患者と医療スタッフ側の回答率はともに $100 \%$ であった，以下に調查した結果を示す。

\section{1. 患者服薬率（図 1)}

処方されている薬剤数は一人当たり 1 日平均 $9.8 \pm$ 3.4 鼡であった，最も服薬率が高かった薬剂はシナカ ルセ卜塩酸塩で $97.4 \pm 5.9 \%$, 次に活性型ビタミン $\mathrm{D}_{3}$ 製 剂の $92.5 \pm 14.5 \%$, 消化性潰瘍剤 $92.3 \pm 14.7 \%$, 降圧剂 $92.3 \pm 14.0 \%$ ，催眠・鎮静剤 $91.9 \pm 15.5 \%$ であった。一 方で，リン吸着剤 $85.5 \pm 18.0 \%$ ，緩下剂 $83.8 \pm 24.7 \%$, カリウム抑制剤 $79.4 \pm 25.5 \%$ とこれら薬剤は比較的低 い傾向であった。

\section{2. 患者服薬率と医療スタッフ予測の比較（図 1）}

医療スタッフが予測する服薬率 $(\mathrm{M})$ と，患者自己 申告による服薬率 $(\mathrm{P})$ の比率 (以下, $\mathrm{P} / \mathrm{M}$ 值) は, シナカルセ卜塩酸塩で $\mathrm{P} / \mathrm{M}$ 值 1.59 と, ほかの薬郕に 比較して高かった。またりン吸着剂 1.38 , 活性型ビ夕 ミン $\mathrm{D}_{3}$ 製剂 1.36 , 降圧剤 1.23 , 消化性潰瘍剂 1.19 , 催 眠・鎮静剂 1.18 , カリウム抑制剂 1.17 , 緩下剂 1.07 と, すべての薬戍において患者の服薬率がスタッフの予測 を有意に上回る結果であった．

\section{3. 飲み忘れの有無とその理由（表 2）}

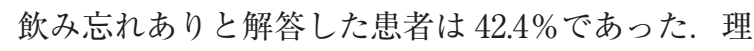
由として「外出に持っていくのを忘れる」,「持参して も人と食事をすると忘れる」,「仕事中は忘れるまたは 忙しくて飲めない」という理由があげられた。

\section{4. 服薬自己調節の有無とその理由（表 2）}

自己調節ありと解答した患者は $28.5 \%$ であった。自 己調節の理由として，降圧薬や緩下剤などは「症状に 合わせて調節する」, 消化性潰瘍凨やリン吸着剤, カリ ウム抑制剤などは「欠食した時は飲まない」,「仕事で 時間がずれ次の服薬時間が近いと飲まない」という理 由があげられた。

\section{5. 年代別服薬率 (表 3)}

消化性潰瘍剤と降圧剤では 65 歳未満の患者でそれ ぞれ $90.0 \pm 17.9 \%, 87.9 \pm 16.3 \%$ で 65 歳以上の高齢者で それぞれ $95.9 \pm 8.4 \%, 95.5 \pm 9.1 \%$ と 65 歳以上の高齢者 で服薬率が有意に高かった $(\mathrm{p}=0.002, \mathrm{p}=0.007)$.

\section{6. 透析時間帯別服薬率（表 4)}

消化性潰瘍剤と緩下剂では 2 クール (午後) の患者 でそれぞれ $95.3 \pm 10.9 \% ， 92.5 \pm 21.0 \%$ で 3 クール（夜 間）の患者でそれぞれ $82.8 \pm 21.5 \% ， 60.5 \pm 19.4 \%$ と 2 クールの患者服薬率が有意に高かった $(\mathrm{p}=0.018, \mathrm{p}<$ 
表 2 飲み忘れと服薬自己調節の有無とその理由

\begin{tabular}{|c|c|c|c|}
\hline \multicolumn{2}{|c|}{ 飲み忘れ } & \multicolumn{2}{|c|}{ 内服自己調節 } \\
\hline あり（n=73） & なし $(\mathrm{n}=99)$ & あり（n=49） & なし $(\mathrm{n}=123)$ \\
\hline $42.4 \%$ & $57.5 \%$ & $28.5 \%$ & $71.5 \%$ \\
\hline \multicolumn{2}{|c|}{ 飲み忘れの理由 } & \multicolumn{2}{|c|}{ 自己調節の理由 } \\
\hline \multicolumn{2}{|c|}{ 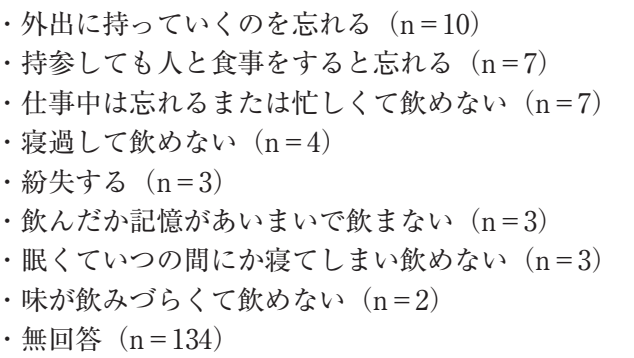 } & \multicolumn{2}{|c|}{ 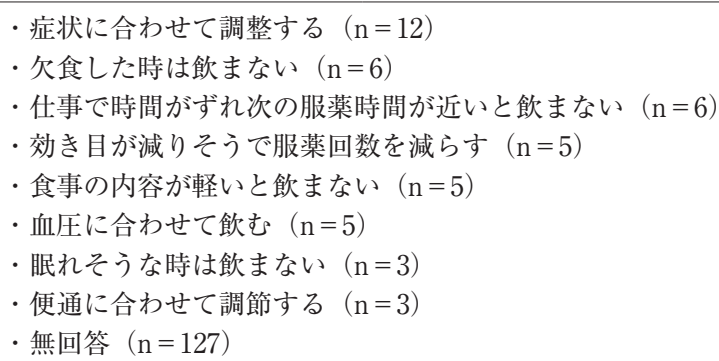 } \\
\hline
\end{tabular}

表 3 年代別服薬率

\begin{tabular}{|c|c|c|c|}
\hline 項目 & 65 歳未満（n=108） & 65 歳以上 $(n=64)$ & p-value \\
\hline シナカルセト塩酸塩 & $96.5 \pm 6.4 \%$ & $98.8 \pm 3.3 \%$ & n.s. \\
\hline 催眠・鎮静剤 & $91.4 \pm 19.5 \%$ & $90.9 \pm 11.6 \%$ & n.s. \\
\hline 活性型ビタミン D製剤 & $89.3 \pm 15.5 \%$ & $95.9 \pm 17.7 \%$ & n.s. \\
\hline 消化性潰瘍剤 & $90.0 \pm 17.9 \%$ & $95.9 \pm 8.4 \%$ & $\mathrm{p}=0.002$ \\
\hline 降圧剤 & $87.9 \pm 16.3 \%$ & $95.5 \pm 9.1 \%$ & $\mathrm{p}=0.007$ \\
\hline 緩下剽 & $83.9 \pm 26.6 \%$ & $87.6 \pm 24.8 \%$ & n.s. \\
\hline リン吸着剤 & $77.6 \pm 18.3 \%$ & $85.3 \pm 18.0 \%$ & n.s. \\
\hline カリウム抑制剂 & $75.2 \pm 27.3 \%$ & $84.6 \pm 24.1 \%$ & n.s. \\
\hline
\end{tabular}

Student's t-test

表 4 透析時間帯 (クール別) 服薬率

\begin{tabular}{|c|c|c|c|c|}
\hline 項目 & 1 クール $($ 午前 $\mathrm{n}=76)$ & 2 クール (午後 $\mathrm{n}=61)$ & 3 クール（夜間 $\mathrm{n}=35 ）$ & $\mathrm{p}$-value \\
\hline シナカルセト塩酸塩 & $97.3 \pm 5.9 \%$ & $99.2 \pm 2.7 \%$ & $95.0 \pm 7.3 \%$ & n.s. \\
\hline 催眠·鎮静剂 & $90.9 \pm 16.0 \%$ & $98.7 \pm 31 \%$ & $83.3 \pm 23.3 \%$ & n.s. \\
\hline 活性型ビタミン $\mathrm{D}_{3}$ 製剤 & $93.3 \pm 15.3 \%$ & $94.5 \pm 9.5 \%$ & $84.6 \pm 19.8 \%$ & n.s. \\
\hline 消化性潰瘍剂 & $93.2 \pm 13.5 \%$ & $95.3 \pm 10.9 \%$ & $82.8 \pm 21.5 \%$ & $\mathrm{p}=0.018$ \\
\hline 降圧剂 & $94.1 \pm 10.3 \%$ & $93.3 \pm 15.2 \%$ & $86.4 \pm 17.3 \%$ & n.s. \\
\hline 緩下剂 & $83.7 \pm 24.8 \%$ & $92.5 \pm 21.0 \%$ & $60.5 \pm 19.4 \%$ & $\mathrm{p}<0.001$ \\
\hline リン吸着剂 & $85.6 \pm 18.5 \%$ & $89.2 \pm 14.8 \%$ & $79.5 \pm 2.0 \%$ & n.s. \\
\hline カリウム抑制剂 & $78.2 \pm 28.3 \%$ & $84.4 \pm 20.0 \%$ & $76.4 \pm 24.2 \%$ & n.s. \\
\hline
\end{tabular}

Kruskal-Wallis test

表 5 処方剂数別服薬率

\begin{tabular}{|c|c|c|c|c|}
\hline 項目 & $3 \sim 6$ 剂 $(n=25)$ & $7 \sim 10$ 凨 $(\mathrm{n}=83)$ & $11 \sim 14$ 剂 $(\mathrm{n}=45)$ & 15 18 剤 $(\mathrm{n}=19)$ \\
\hline シナカルセト塩酸塩 & $97.5 \pm 6.3 \%$ & $96.9 \pm 6.2 \%$ & $97.7 \pm 3.4 \%$ & $93.3 \pm 11.5 \%$ \\
\hline 催眠・鎮静剂 & $100.0 \%$ & $91.9 \pm 17.5 \%$ & $93.3 \pm 12.6 \%$ & $89.1 \pm 17.8 \%$ \\
\hline 活性型ビタミン $\mathrm{D}_{3}$ 製剤 & $92.8 \pm 11.1 \%$ & $88.9 \pm 18.2 \%$ & $97.9 \pm 3.8 \%$ & $95.8 \pm 7.9 \%$ \\
\hline 消化性潰瘍荗 & $95.6 \pm 12.6 \%$ & $90.1 \pm 16.6 \%$ & $95.2 \pm 10.9 \%$ & $91.4 \pm 14.5 \%$ \\
\hline 降圧剂 & $95.2 \pm 10.3 \%$ & $90.9 \pm 14.9 \%$ & $94.6 \pm 12.9 \%$ & $88.3 \pm 15.8 \%$ \\
\hline 緩下剂 & $87.5 \pm 25 \%$ & $88.5 \pm 19.7 \%$ & $75.4 \pm 31.1 \%$ & $85 \pm 22.1 \%$ \\
\hline リン吸着剤 & $83.5 \pm 17.2 \%$ & $83.8 \pm 18.3 \%$ & $87.5 \pm 18.9 \%$ & $89.4 \pm 15.6 \%$ \\
\hline カリウム抑制剂 & $90 \pm 14.1 \%$ & $78.3 \pm 24.6 \%$ & $70.4 \pm 31.2 \%$ & $94.2 \pm 11.3 \%$ \\
\hline
\end{tabular}

Kruskal-Wallis test

処方剂数別服薬率で統計学的有意差なし

0.001).

\section{7. 処方剂数別服薬率（表 5)}

処方剂数別では 1 日処方剂数を 4 錠ごとに 4 群に分
けて行い検討したが，処方剤数別による差は認められ なかった。 


\section{8. リン吸着剂における種類別服薬率（表 6)}

リン吸着剤では種類別に炭酸カルシウム OD 錠・炭 酸カルシウム粉末・クエン酸第二鉄水和物・ビキサロ マー・炭酸ランタン水和物顆粒・炭酸ランタン水和物 チュアブル錠の服薬率に差は認められなかった.

\section{9. カリウム抑制剤における種類別服薬率（表 7)}

カリウム抑制剤では種類別にポリスチレンスルホン 酸ナトリウムドライシロップ・ポリスチレンスルホン 酸カルシウムゼリー・ポリスチレンスルホン酸カルシ ウム散・ポリスチレンスルホン酸カルシウム経口液の 服薬率に差は認められなかった。

\section{V. 考 察}

今回われわれの調査の結果, 患者の服薬率と医療又 タッフの予測する服薬率には有意な乘離が認められ, 日常医療スタッフが持っている患者服薬状況に対する 認識を改める必要性が示唆された.

まず患者の服薬率と医療スタッフが予測する服薬率 については, すべての薬剤で P/M 值が 1.0 を超えてお り，患者の服薬率は医療スタッフの予測を上回る結果 であった．特にシナカルセト塩酸塩とリン吸着剤につ いては, それぞれ $\mathrm{P} / \mathrm{M}$ 值 $1.59,1.38$ であり, 医療ス タッフの予測との乘離が大きく, これらの薬剤が吐気 等消化器症状の発症頻度が比較的高いことから $5^{6 \sim 8)}$, 医療スタッフ側としては患者の服薬が困難であるとの 先入観を抱いていた可能性がある. またわれわれ医療 スタッフは, 生化学検査值から患者状態を評価してい るが，例えば薬を増量したが血清リン值が不変である

\section{表 6 リン吸着剂種類別服薬率}

\begin{tabular}{c|c}
\hline 項目 & 服薬率 \\
\hline 炭酸カルシウム $\mathrm{OD}$ 錠 $(\mathrm{n}=8)$ & $86.8 \pm 19.3 \%$ \\
炭酸カルシウム粉末 $(\mathrm{n}=78)$ & $83.1 \pm 11.9 \%$ \\
クエン酸第二鉄水和物 $(\mathrm{n}=15)$ & $82.3 \pm 15.6 \%$ \\
ビキサロマー $(\mathrm{n}=24)$ & $80.6 \pm 21.4 \%$ \\
炭酸ランタン水和物顆粒 $(\mathrm{n}=29)$ & $78.3 \pm 18.5 \%$ \\
炭酸ランタン水和物チュアブル錠 $(\mathrm{n}=21)$ & $76.9 \pm 18.5 \%$ \\
\hline \multicolumn{2}{c|}{ Kruskal-Wallis test 群間で統計学的有意差なし }
\end{tabular}

場合，「薬を飲んでいないからリン值が低下しないの であろう」等の固定観念で, 患者を評価し結論を導い ている可能性も否めない. しかしながら患者の服薬ア ドヒアランスは医療スタッフの予測に相反する結果で あり，これらの憶測についてわれわれ医療スタッフは 猛省する必要がある.

次に，患者の服薬傾向について述べる．今回の調査

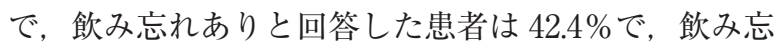
れの理由として「仕事中は忘れるまたは忙しくて飲め ない」，「持参しても人と食事をすると忘れる」等があ げられた。過去の研究においても, 一般病院での服薬 コンプライアンスに関する調査では, 約 50\% 60\%の 患者は服薬を忘れたことがあると報告されており ${ }^{9)}$, 今回の調查と類似している結果であった。 また服薬の 自己調節があると回答した患者は $28.5 \%$ で, 理由とし て「症状に合わせて調節する」，「仕事で時間がずれ次 の服薬時間が近いと飲まない」等があげられたことよ り，透析患者における「仕事」という一つのキーワー ドは, 時間的拘束が大きく, 必然的に服薬夕イミング のずれを生じさせ, 透析患者における服薬アドヒアラ ンス低下に大きく関与している可能性が示唆された。 これを裏付けるように, 透析時間帯別による薬剤の服 薬率は, 消化性潰瘍剤において 2 クール $95.3 \pm 10.9 \%$, 3 クール $82.8 \pm 21.5 \% （ \mathrm{p}=0.018)$, 緩下剤で 2 クール $92.5 \pm 21.0 \%, 3$ クール $60.5 \pm 19.4 \%(\mathrm{p}<0.001)$ と 3 クールの患者と比ベ 2 クールの患者では有意に服薬率 が高く, 年代別による薬剤の服薬率では消化性潰瘍剤 で 65 歳未満が $90.0 \pm 17.9 \%$ ， 65 歳以上が $95.9 \pm 8.4 \%$ $(p=0.002)$, 降圧剤で 65 歳未満 $87.9 \pm 16.3 \%, 65$ 歳以 上が $95.5 \pm 9.1 \%(\mathrm{p}=0.007)$ で 65 歳以上の高齢者で有 意に服薬率が高かった。この結果からも, 比較的年齢 が若く社会活動性が高い，いわゆる「仕事」に従事し ている透析患者は, 服薬アドヒアランスが低下する傾 向が示された. また共通して自己調節を行っていた薬 剤は消化性潰瘍剂で, 慢性腎不全の約 $70 \%$ に消化器症 状の訴えがあったと報告されているように10), 消化器 症状は自覚症状が強い反面, 無症状の場合には, 定時 処方でありながら自己調節可能な薬剤として識別され

\begin{tabular}{c|c}
\hline \multicolumn{1}{c}{ 項目 } & 服薬率 \\
\hline ポリスチレンスルホン酸ナトリウムドライシロップ $(\mathrm{n}=7)$ & $85.3 \pm 33.8 \%$ \\
ポリスチレンスルホン酸カルシウムゼリー $(\mathrm{n}=3)$ & $77.9 \pm 22.5 \%$ \\
ポリスチレンスルホン酸カルシウム散 $(\mathrm{n}=7)$ & $74.0 \pm 30.0 \%$ \\
ポリスチレンスルホン酸カルシウム経口液 $\quad(\mathrm{n}=16)$ & $71.7 \pm 14.5 \%$ \\
\hline
\end{tabular}


ている可能性が考えられた．便通に応じて調節可能な 緩下郕や家庭血圧に応じて自己調節できる降圧薬につ いても同様であると思われる。一方，リン吸着剤にお いては，処方数が増加するほど服薬アドヒアランスの 低下につながるとの報告もあり ${ }^{11)}$ ，当院のリン吸着剤 の服薬率が, 他剤と比較し低下した要因と思われる. また，カリウム抑制剤については，形態により服薬ア ドヒアランスは低下するとの報告から ${ }^{12)}$ ，これらの薬 鼡に関しては, 薬剤の形体や錠数による影響により, 服薬アドヒアランスが低下する根本的要因である可能 性が示唆された。

現代医療の方向性は医療スタッフと患者で十分な情 報と意思を共有し，治療方法の選択を行うコンコーダ ンスへ向かっている ${ }^{13)}$. 今回の調查研究の結果は, 服 薬遵守に関する情報と意思共有，そして処方後の服薬 状況の確認, 意思疎通が患者と医療スタッフで十分に なされていないことを示して抢り，医療スタッフから の適切なアプローチがなされていなかった可能性が考 えられる. 2015 年での透析医療費実態調查報告で は14)，処方は増加傾向であり医療費に影響を与えてい ることを示唆しており, 過多な処方は医療経済的にも 厳に問題視しなければならない。また，リン吸着剤に ついては, 処方数が増すほどアドヒアランスは低下 し, 血清リン高值とも関連するという興味深い報告が 昨年の本誌になされておりり ${ }^{11)}$, 今後は疾患・病態の説 明から始まり, 薬物療法の意味, 服薬遵守しなかった 場合のリスクまで説明する患者教育の重要性のみなら ず，われわれ医療スタッフ自身の薬剤に関する知識の 充実と，患者の服薬状況を客観的に評価する姿勢が求 められる。 また，今回のように定期的な服薬率調查を 継続することで，質のよい服薬アドヒアランスが達成 される可能性が示された.

\section{結語}

今回の調査では患者の服薬率と医療スタッフが予測 する服薬率を比較し，その差異について検討した結 果, すべての薬剂で患者の服薬率が高い傾向であっ た．この医療スタッフの予測する服薬率との靟離には 多くの因子を考虑する必要があり，とりわけ患者と医 療スタッフの服薬に関するコミュニケーションは重要 なポイントと考える．患者のリスクや医療費の増加を 減らすためにも，今後は患者・医療スタッフともに服 薬遵守に関する情報と意思を共有するシステムの構築
が必要であると思われた.

利益相反：申告すべきものなし．

\section{文献}

1）日本透析医学会統計調查委員会. 図説 わが国の慢性 透析療法の現況 2015 年 12 月 31 日現在. 東京：日本透 析医学会, 2016.

2）田中昭人，鈴木晃，溝口淳子，杉江八江子，杉村みゆ き. 透析患者に扔ける服薬実態調査. 医薬ジャーナル 1983; 11:2203-9.

3）工藤英範，南茂，斎藤司，他，慢性腎不全患者の血管 および心臟手術時の体外循環. 体外循環技 1992；18： 75-80.

4）高橋信好, 鈴木唯司, 佐藤元昭, 他. 慢性腎不全患者 の腰椎骨塩量の検討一quantitative computed tomography 法と dual energy X-ray absorptiometry 法の比 較一. 透析会誌 1996；29：1191-9.

5）都築泉, 井上智恵子, 浅越泉. 血液透析患者の服薬実 態調查と問題点. 医薬ジャーナル 1986；22：767-73.

6）高津千裕，古久保拓，松永千春，他. 透析患者の二次 性副甲状腺機能光進症に対するシナカルセ卜䜖酸塩投 与時の副作用発現状況の調查. 透析会誌 2009；42： 931-8.

7）伊達敏行, 川下誉晃, 佐竹伸由. 慢性血液透析症例に おける Colestimide のリン吸着剤としての有用性. 透 析会誌 2001；34：111-7.

8）森慶太, 越川真男, 明石健吾, 他. 炭酸ランタンの腸 管内遺残を認めた血液透析患者の 1 例。透析会誌 2010；43：853-7.

9）林誠，竹尾恵理子，岡田守弘，後藤一純，入谷健，鈴 木達男．虚血性心疾患に押ける服薬アンケート調查と コンプライアンス向上に関する検討。日病薬師会誌 2004; 41: 1403-6.

10) Shirazian S, Radhakrishnan J. Gastrointestinal disorders and renal failure: exploring the connection. Nat Rev Nephrol 2010； 6: 480-92.

11）伊藤恭子, 永野伸郎, 高橋伴彰, 他. リン吸着薬処方 銫数の増加は服薬アドヒアランス低下抢よびリン管理 不良と関連する。透析会誌 2016；49：475-82.

12）高島孝次郎，水野賀夫，有田光一，五十嵐茂幸，潮木 保幸，血液透析患者におけるアーガメイトゼリーおよ びカリメートの比較検討. 医療薬 2004；30：584-7.

13) Paut Kusturica M, Tomas A, Sabo A. Disposal of Unused Drugs: Knowledge and Behavior Among People Around the World. Rev Environ Contam Toxicol 2017; 240: 71-104.

14）太田圭洋, 宍戸寬治, 土谷晋一郎，他. 第 19 回透析医 療費実態調查報告. 日透析医会誌 2016；31：90-103. 